\title{
The economic impacts of increased grazing fees on Gila National Forest grazing permittees
}

\author{
L. ALLEN TORELL AND TRACY W. DRUMMOND
}

Authors are professor and former graduate student, Department of Agricultural Economics and Agricultural Business, New Mexico State University, Las Cruces, N.M. 88003-3169.

\section{Abstract}

The purpose of this research was to estimate the impacts of increased federal grazing fees on current holders of grazing permits on the Gila National Forest (GNF) in western New Mexico. A multi-period linear programming (LP) model was developed using 1992 national forest ranch budgets as baseline data. Discounted net returns (returns over variable costs) were maximized over a 60-year planning horizon under current fee regulations, and with alternative fees computed for various recent legislative and administrative grazing fee proposals. Small, medium, and large ranches were considered in the impact assessment. In addition to livestock income and expenses, off-ranch income, family living expenses, and debt obligations were directly considered in the analysis.

An estimated $7 \%$ of the current Gila National Forest grazing permit holders - those medium and large ranches with high debt -would be expected to go out of business even if the current grazing fee were continued. At a federal grazing fee of \$3.96/AUM as proposed by Rangeland Reform '94, an additional $20 \%$ of GNF permittees would be expected to go out of business. These would be the small high-debt ranches and large ranches with intermediate levels of debt. A grazing fee of \$8.70/AUM would be expected to cause all current GNF ranchers with debt to go out of business.

Average annual USFS grazing use by existing permit holders was estimated to decrease by about 120,000 AUMs when the grazing fee was increased to $\$ 3.96 / \mathbf{A U M}$, but grazing fee receipts would increase by $31 \%$ with the higher fee, assuming no new permit holders or consolidations occurred. The largest grazing fee receipts were generated at the \$3.96/AUM fee.

Key Words: public land policy, grazing fees, Rangeland Reform '94, linear programming.

Grazing fees and the use of public rangelands is a continuing controversy. A 1994 proposal called Rangeland Reform '94 created a forum for continued debate about the grazing use of western public rangelands. Under the Bureau of Land Management (BLM) and U.S. Forest Service (USFS) preferred management alternative, as outlined in Rangeland Reform '94 (USDI/USDA 1994a, pp. 2-8-2-18), public land grazing fees would double, grazing advisory boards would be replaced with multiple resource advisory boards, new range conservation standards

This article is published cooperatively with the New Mexico Agr. Exp. Sta., New Mexico State University, Las Cruces, N.M.

Manuscript accepted 1 Jan. 1996. would be imposed, rules and regulations would be enforced more strongly, subleasing of federal land would be penalized, and ownership of new range improvements would be vested to the federal government.

These reform proposals have been perceived to greatly alter the administration and use of western public lands. Most public land ranchers see implementation of Rangeland Reform '94 as the end of their livelihood and way of life. This has created renewed interest in state and/or private ownership of the public domain and elicited thousands of comments both for and against the reform proposal.

As a result of the debate and controversy about public land management, federal land agencies backed away from implementing new land use regulations and did not increase the grazing fee. Congressional legislation was introduced to address many of the proposals included in Rangeland Reform ' 94 but they also have not been adopted. The controversy continues and it is possible, if not anticipated, that some of the proposals, including a higher grazing fee, will eventually be implemented.

Rangeland Reform ' 94 has not been the only recent attempt to increase public land grazing fees; rather, it has been an annual event since grazing fee studies were completed in 1986 (USDA/USDI 1986). Various grazing fee formulas have been proposed, ranging from continuing the current Public Rangeland Improvement Act (PRIA) fee (\$1.98/AUM in 1994) to the \$8.70/AUM fee proposed by Congressmen Synar, Darden, and Atkins (Synar et al. 1991).

It is widely believed that small ranch operations would be impacted most by higher grazing fees and altered land use policies; special breaks have been proposed for small part-time ranchers using public lands (Nadler 1995). Cost and return estimates for small ranch operations continually show negative returns to ranch investment (when opportunity costs are included), and the perception is that these ranches are vulnerable to higher fees and more costly land use policies. Yet, when nonfarm income is considered it is not clear who would be most affected by altered land use policies. Operators of small ranches or other family members generally work off the ranch, and a major part of disposable family income comes from non-farm sources. Other factors including debt level and level of public land dependency would be expected to be equally important when evaluating ranch specific impacts of altered public land use policies.

Numerous studies were conducted which estimated the potential impacts of BLM policy changes proposed in Environmental Impact Statements (EISs) written in the 1970's and 1980's (Gee 1981, Olson and Jackson 1975, Peryam and Olson 1975, Torell et 
al. 1981, Wilson et al. 1985). These earlier studies generally found that the potential impact of increased grazing fees and altered land use policies depended largely on the level of federal land dependency and the equity position of the ranch owner. Changing the allowed season of use or stocking rate was found to have a much larger impact on net ranch returns and optimal production strategies than doubling the grazing fee (Torell et al. 1981).

Several recent studies have estimated the impact of higher grazing fees proposed under Rangeland Reform `94. Using a simulation model for ranches in Montana, Wyoming, Colorado, and New Mexico, Richardson et al. (1993) estimated the \$4.28/AUM fee initially proposed by BLM and USFS in Rangeland Reform ' 94 (USDI/USDA 1993) would not force ranchers out of business over the next 6 years, though it would reduce income and net worth. Similarly, the BLM and USFS concluded in the Draft EIS for Rangeland Reform `94 that initiating the BLM/USFS proposed action alternative would be similar to continuing current management over the long tcrm. Continued growth in employment and income in other sectors was projected to compensate for the relatively small employment and income reductions caused by decreases in reduced federal forage use (USDA/USDI 1994b, p. 33). The income loss was estimated to vary in direct proportion to the level of dependency on federal rangeland. This strong relationship between lost income and level of dependency was also evident in a budgeting assessment of Rangeland Reform '94 impacts to New Mexico ranchers (Torell et al. 1994).

The objective of this research was to estimate the ranch-level impacts of grazing fee increases proposed in Rangeland Reform ' 94 and in earlier fee legislation. These alternative fee proposals plus the current PRIA fee formula cover the range in value over which future grazing fees will most likely be established.

The impacts to ranchers currently using the Gila National Forest (GNF) in western New Mexico are considered. Ranchers in this area depend heavily on public land forage. USFS allotments are grazed yearlong and GNF ranchers depend on public land grazing for almost all yearlong grazing capacity.

\section{Methods, Procedures, and Model Development}

A multi-period linear programming (LP) model was developed that optimizes the net present value (NPV) of returns over variable costs for small, medium, and large ranches using the Gila National Forest (GNF). Ranch budgets prepared by Torell et al. $(1993 a, b, c)$ were used to define typical production rates, production practices, costs, and returns for cow/calf ranches using the GNF during the 1992 production year. Gross livestock receipts, return over variable costs, and the residual return to ranch investment were used as measures of ranch profitability under each grazing fee scenario. Optimal AUM use for the GNF was estimated under each fee rate, along with grazing fee receipts from current permit holders.

\section{The Multi-Period Linear Programming Model}

Linear programming is a mathematical procedure that maximizes or minimizes a linear objective function subject to a set of linear constraints that define resource use and limits. Ranch management applications typically define a linear profit function, and this function is maximized subject to linear constraints that define seasonal resource limits, forage use rates, production relationships and transfer rates between various production and sale activities.

Past studies using linear programming (LP) to evaluate altered land use policies have considered a single-year model; the objective of the model was to maximize returns over a single production period (e.g., Gee 1981, Olson and Jackson 1975, Peryam and Olson 1975, Torell et al. 1981, Wilson et al. 1985).

A limitation of the single-period LP model is that inter-year variation and dependence of variables like cash flows, debt repayment capacity, herd size, and forage production, among others, are not explicitly recognized or considered. In addition, average prices and costs are usually defined for a typical or average production year (Gee 1981, Torell et al. 1981, Wilson et al. 1985 ), but this averaging procedure may suggest production strategies that would not be optimal when inter-year linkages and dependencies are considered.

The LP model developed for this study is a multi-period profitmaximizing model that removes many of these limitations. Livestock production is considered to take place over $\mathrm{T}$ years. Similar to the single-period model formulation, there are alternative production and marketing activities that could potentially be used each year, but some of these activities. now include the transfer of resources (e.g., cows, operating capital) between years. Production during any given year is limited by available resources that year and the transfer of resources from previous years.

The problem is to maximize the NPV of economic returns from livestock production over the $\mathrm{T}$-year planning horizon. Mathematically, the problem can be stated as

Maximize $Z=C_{1} X_{1}+C_{2} X_{2}(1+r)^{-1}+\ldots+C_{T} X_{T}(1+r)^{1-T}$

subject to the restrictions:

$$
\begin{aligned}
& A_{11} X_{1} \quad\{\leq=\geq\} B_{1} \\
& A_{21} X_{1}+A_{22} X_{2} \quad\{\leq=\geq\} B_{2} \\
& \text { : } \quad \because \quad \text { a } \\
& \dot{A}_{k 1} X_{1}+A_{k 2} X_{2}+\ldots+A_{k k} X_{k} \quad\{\leq=\geq\} B_{k} \\
& A_{(k+1) 2} X_{2}+A_{(k+1) 3} X_{3}+\ldots+A_{(k+1)(k+1)} X_{k+1} \quad\{\leq=\geq\} B_{k+1}
\end{aligned}
$$

$\mathrm{A}_{\mathrm{T}(\mathrm{T}-\mathrm{k})} \mathrm{X}_{\mathrm{T}-\mathrm{k}}+\ldots+\mathrm{A}_{\mathrm{TT}} \mathrm{X}_{\mathrm{T}}$

$\{\leq=\geq\} B_{T}$

With this multi-period formulation, the production activities and restrictions of the LP model are partitioned by year. Each $X_{t}$ defines the production activities for year $t$. Similarly, $C_{t}$ defines the per-unit prices and costs defined for year $t$, but this matrix is now multiplied by the discount factor given by $(1+r)^{1-t}$, where $r$ is the discount rate used to discount future returns.

The diagonal matrices of the constraint set, as given by $A_{t}$, define the within-year input-output coefficients, while those below and to the left of the diagonal refer to between-year coefficients. The between-year coefficients provide for the transfer of resources between years, and $A_{t(t-1)}$ will include most of these transfers. An example is the transfer of brood cows and cash balances from year $t-1$ to year $t$.

Other production activities may interact with activities in the more distant past and matrices $A_{t(t-2)}, A_{t(t-3)}, \ldots, A_{t(t-k)}$ are included to capture these interactions. An example would be intermediate borrowing with an anticipated payback (cash requirement) over the next $\mathrm{k}$ years. 
The major activities in the model included forage harvesting, the raising and sale of livestock, and borrowing and repayment of debt. The major resource restrictions of the model included available forage and cash. In addition, equations were included to transfer furage, establish typical ratios between classes of livestock, transfer livestock raised to sale activities, and transfer brood stock and cash balances between years.

Three types of forage (USFS, state trust land, and deeded land) could potentially be harvested each year. Profit-maximizing resource use was considered with no minimum-use restrictions imposed. Forage requirements for various animal classes were defined using standard animal unit (AU) equivalency factors.

Equations defining animal class ratios included calf crop, minimum cow replacement rates, maximum number of cows to be replaced with raised heifer calves, and the number of horses. Animal classes that could be sold included cull animals, brood cows, weaned calves, and raised yearlings. Yearlings were transferred between the raise activity at $t-1$ and the sell activity at $t$. This is the first linkage between years.

A cow transfer equation was included as an accounting restriction. This equation limited the source of brood cows during year $t$ to include those raised during period t-1 (less a death loss), replacements raised in period $\mathrm{t}-1$ or cows purchased at time $t$. Three production options were available for cows transferred: they could be raised again at time t, they could be sold, or they could be culled, which reduced the number of cows available for further transfer. An initial endowment of brood cows was included during year 1 as defined in the representative Gila National Forest (GNF) ranch budgets. Optimal herd size during other years was determined within the model. Because each animal class raised at time $t$ is expressed as a ratio to the number of brood cows, the cow transfer equation limits the production of all livestock classes.

Livestock sales revenue at time $t$ can be used to meet production expenses at time $t$, to repay short- and intermediate-term debt obligations, or used to purchase brood animals. In addition, a residual amount must remain to provide for payment of family living expenses, fixed costs, and long-term debt obligations. Offranch income is included as an additional source of income.

If funds are limiting, and if profit maximizing, borrowing can be with either an intermediate or short-term payback. The equation structure allows short-term borrowing to purchase intermediate assets (brood stock) but not the use of intermediate borrowing to cover short-term expenses. Equations are included that force everything borrowed to be repaid.

Intermediate-term borrowing is repaid over 5 years, with cash balances reduced over this repayment period by the amount of the amortized principal and interest payment. Intermediate-term borrowing is not allowed in the last 5 years of the planning horizon to assure all debts are repaid. Further, additional long-term borrowing is not considered. The model assumes a long-term debt obligation is already in place and restrictions require the repayment of this loan over a 30 -year period.

A borrowing limit was included to restrict the amount that could be borrowed at time $t$. For the initial runs with current grazing fees, this limit was set at $70 \%$ of the asset value defined for each representative ranch budget. It was assumed that increased grazing fees would eliminate the market value of grazing permits, thus, for those runs considering increased fees, the estimated market value of grazing permits was subtracted from the asset value.

The multi-period linear programming (LP) model maximizes discounted net returns over 60 years $(T=60)$. For practical pur- poses this is equivalent to maximizing returns over an infinite planning horizon, because at a positive discount rate the NPV of returns beyond this point are nearly zero.

Fixed costs, family living expenses, and debt obligations were subtracted from the model objective function (optimal return over variable costs) to compute residual returns to owned ranch capital. Net present value was determined using a $7 \%$ discount rate. All costs and prices were assumed to remain constant at 1992 levels in real terms. The $7 \%$ discount rate reflects a $3-4 \%$ real rate of return plus a risk premium.

Table 1 defines the production and marketing activities included in the LP model, along with the objective function coefficient used for each activity. Table 2 further defines livestock prices that varied by year. A more complete description of the LP model is provided by Drummond (1993), including definition of the LP matrix tableau, specific equations and activities, a detailed summary of optimal solution values, and the computer code for the GAMS (General Algebraic Modeling System) programming model (Brooke et al. 1992) used in the analysis.

\section{Defining the LP model for the Gila National Forest General Model Parameters}

Production parameters and the resource base for each ranch size are shown in Table 3 and a summary of costs and returns for the 1992 production year is given in Table 4. This summary includes each of the ranch sizes and 3 different initial debt loads assumed in the analysis. Income consisted of gross livestock sales and outside or off-ranch income, which was defined from New Mexico data compiled from a 1991 Western Livestock Producers Alliance funded survey (Fowler et al. 1994). This survey, conducted in 14 western states, compiled information about rancher revenue and expenditures in rural communities. It was found that small- and medium-size ranches generally have at least 1 person or full time equivalent (FTE) working off the ranch to supplement ranch income. Large-size ranches have an average of 0.75 FTE working off the ranch. It was then assumed that small and medium size ranches had 1.0 FTE in off-ranch income, and the large ranch had 0.75 FTE. An average wage rate of $\$ 9 /$ hour for 2,000 hours per FTE was used to compute off-ranch income (New Mexico Economic Development Dept. 1992). The total assumed salary is similar to the $\$ 23,000$ average off-ranch income reported by participants of a $1990 \mathrm{New}$ Mexico finance survey (NMDA 1990).

Off-ranch income is crucial to the analysis. As shown in Table 4, if off-ranch income were not available for the 1992 production year, only the medium and large ranches with no debt would have positive net income after production expenses and debt obligations were considered. Only the medium and large representative ranches with little if any debt could remain in business without outside income.

Overhead expenses were divided into 3 categories: a family living allowance, fixed ranch expenses, and capital improvement. The family living allowance included items such as groceries, clothing, medical expenses, recreation, and others, as defined for New Mexico by the Western Livestock Producers Alliance cost survey. Fixed ranch expenses include telephone, electricity, heating, insurance, and property taxes, as defined by NMSU ranch budgets (Torell et al. 1993a,b,c). Capital improvement is a depreciation allowance for replacement of range improvements, equipment, and machinery. The level of herd replacement is optimally defined within the linear programming (LP) model and replacement heifers are either bought or saved from the herd for replacement and expansion. 


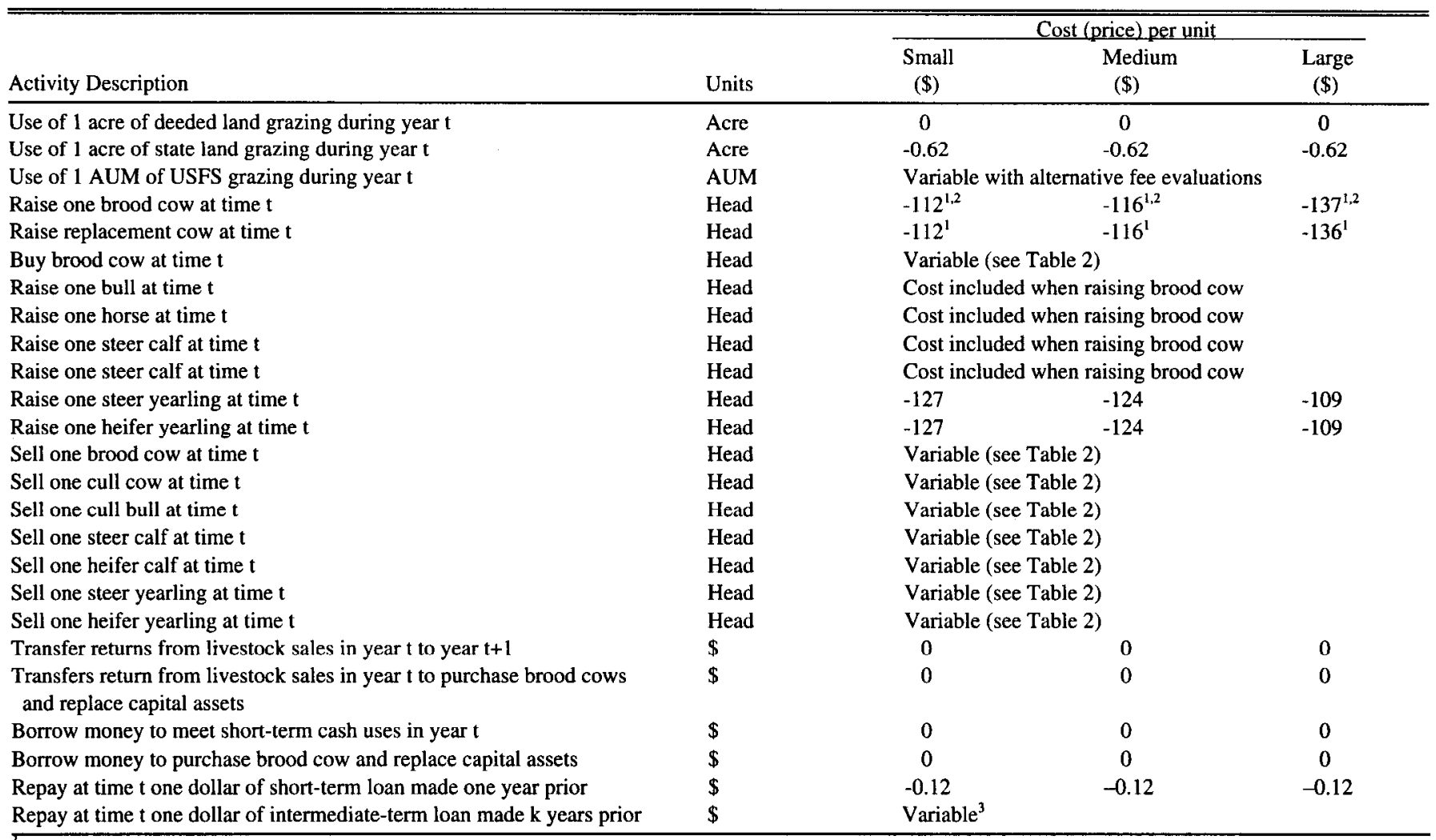

${ }_{2}$ Excludes grazing fees.

${ }^{2}$ Calculated using total variable cost from the appropriate 1992 NMSU ranch budgets minus grazing fees and divided by mature cows and replacements. The cost per cow will not be the same per cow cost reported by Torell et al. $(1993 \mathrm{a}, \mathrm{b}, \mathrm{c})$ because the published budgets do not average costs over replacement heifers.

${ }^{3}$ The interest paid at time $t$ on each dollar of intermediate loan made $k$ years prior was calculated as the loan payment less the principal payment due on the loan.

No debt, a $20 \%$ debt/asset ratio and a $40 \%$ debt/asset ratio were defined to typify the range of debt obligations found on New Mexico ranches, using a 1990 New Mexico Department of Agriculture finance survey (NMDA 1990). This survey found that during $1990,36 \%$ of New Mexico livestock producers reported no debt. Similarly, $52 \%$ reported debt/asset ratios between 0 and $39 \%$, and $12 \%$ had a debt/asset ratio over $40 \%$. To capture the economic profile of the highest debt group, the debt/asset ratio used in the analysis should have been more than $40 \%$. However, initial budgeting and model analysis indicated negative returns and an infeasible solution for the LP model at debt levels at or above $40 \%$. Net income was negative for the high debt group during 1992, even at the assumed $40 \%$ debt/asset ratio (Table 4). 'These individuals must either have above-average management and production, have off-ranch income or accumulated wealth greater than what was assumed in the modeling analysis, or produce at a lower cost than defined to be representative for Gila National Forest (GNF) ranches.

Prices received for livestock varied each year and were obtained from data compiled for the Clovis, New Mexico livestock auction as an average annual price. Beef prices for 1979 through 1992 were indexed to 1992 levels using the input cost index (ICI), an index constructed to track the cost of raising livestock on western public land ranches (USDA/USDI 1986). The 14-year beef price cycle shown in Table 2 was repeated systematically to define beef prices for the 60 -year linear programming (LP) analysis. Production costs were not indexed because they have not been cyclic but rather exhibit a gradual annual increase similar to the rate of inflation.

\section{Base Runs at the Current PRIA Grazing Fee}

Base runs of the linear programming (LP) model were made using the \$1.92/AUM grazing fee generated from the PRIA fee formula for the 1992 production year. This fee was used for each of the 60 years in the LP analysis. In reality, the PRIA fee formula is indexed to the Beef Cattle Price Index, Prices Paid Index, and Forage Value Index which results in a different fee each year. ' The procedure used assumes the PRIA fee formula would maintain average fees at the constant 1992 rate of $\$ 1.92$ /AUM. Yet, evaluating the formula performance over the past 25 years indicates that PRIA-generated fees declined in real terms and fell further and further behind reported private land lease rates (USDA/USDI 1992). The assumption of constant real fees under PRIA gives a conservative estimate of value change when compared to other fee formulas.

\section{Rangeland Reform '94}

Under the preferred grazing fee policy proposed in Rangeland Reform `94 (USDI/USDA 1994, p. 2-36), grazing fees on BLM and USFS lands would be set by a new formula indexed by the

\footnotetext{
The range in grazing fees under PRIA has been from \$2.41/AUM in 1980 to $\$ 1.35 /$ AUM in $1985-87$.
} 
Table 2. Real (Constant 1992) beef prices (\$/cwt) considered in the LP analysis.

\begin{tabular}{|c|c|c|c|c|c|c|c|c|c|}
\hline \multirow{2}{*}{$\begin{array}{l}\text { Price } \\
\text { Year }\end{array}$} & \multirow{2}{*}{$\begin{array}{l}\text { Year in } \\
\text { the model }\end{array}$} & \multicolumn{2}{|c|}{ Calf } & \multicolumn{2}{|c|}{ Yearling } & \multicolumn{2}{|c|}{$\overline{\text { Cull }}$} & \multicolumn{2}{|c|}{ Brood Cow } \\
\hline & & Steer & Heifer & Steer & Heifer & Cow & $\overline{\text { Bull }}$ & Sell & Buy \\
\hline & & $(\$ / C W T)$ & (\$/CWT) & (\$/CWT) & $(\$ / C W T)$ & (\$/CWT) & $(\$ / C W T)$ & (\$/CWT) & $(\$ / C W T)$ \\
\hline 1979 & $1,15,29,43,57$ & 125.54 & 107.89 & 103.85 & 93.51 & 67.56 & 79.53 & 522 & 580 \\
\hline 1981 & $3,17,31,45,59$ & 72.58 & 61.53 & 65.62 & 57.80 & 44.00 & 51.23 & 492 & 547 \\
\hline 1982 & $4,18,32,46,60$ & 70.00 & 59.61 & 65.39 & 57.43 & 42.18 & 47.30 & 460 & 511 \\
\hline 1983 & $5,19,33,47$ & 70.53 & 58.69 & 62.39 & 56.18 & 38.93 & 45.02 & 442 & 491 \\
\hline 1986 & $8,22,36,50$ & 80.71 & 66.61 & 66.69 & 58.87 & 41.77 & 47.43 & 440 & 489 \\
\hline 1987 & $9,23,37,51$ & 103.34 & 88.07 & 84.43 & 76.36 & 49.92 & 57.20 & 526 & 584 \\
\hline 1988 & $10,24,38,52$ & 109.01 & 93.65 & 87.68 & 79.79 & 50.88 & 60.42 & 584 & 649 \\
\hline 1989 & $11,25,39,53$ & 103.02 & 88.93 & 83.87 & 76.99 & 48.81 & 59.68 & 587 & 652 \\
\hline 1990 & $12,26,40,54$ & 105.31 & 94.16 & 88.19 & 83.09 & 54.92 & 65.79 & 589 & 654 \\
\hline 1991 & $13,27,41,55$ & 105.48 & 94.18 & 88.00 & 83.02 & 53.70 & 64.52 & 610 & 677 \\
\hline
\end{tabular}

Sources: Market News Reports for the Clovis, N.M. livestock market. Brood cow sale and purchase prices were from selected NMSU livestock cost and return publications and extrapolated for some years when data were not available. The sale price of a brood cow was assumed to be $11 \%$ more than the purchase price to account for marketing and transportation costs. All prices have been adjusted to constant 1992 levels.

forage value index (FVI). The grazing fec would be phased in over 3 years, with the fee set at \$2.75/AUM during the first year, \$3.50/AUM the second, and with full implementation to the base value of \$3.96/AUM during the third year. For the modeling analysis presented here, the phase-in fees were considered during the first 2 years, then the fee was assumed to remain constant in real terms at the $\$ 3.96 / \mathrm{AUM}$ base rate. Only 2 alterations were made relative to the base model: the grazing fee was increased, and the borrowing limit was decreased because it was assumed the market value of federal grazing permits would be eliminated when higher fees were implemented. This assumption is consistent with the findings of Torell and Kincaid (1996), who report a continued decline in public land grazing permit values because of the uncertainty about future grazing fees and public land policies. The average value of representative Gila National Forest (GNF) ranches was estimated using a ranch value model described by Torell and Kincaid (1996). The contributory value of federal grazing permits for small, medium and large GNF ranches were estimated to be $\$ 93,729$ ( $\$ 858 /$ USFS AUY), $\$ 138,266$ (\$656/USFS AUY), and \$193,879 (\$415/USFS AUY), respectively. These estimated permit values were subtracted from the total asset values shown in Table 4 when considering grazing fees higher than \$1.96/AUM.

\section{Synar Grazing Fee Proposal.}

Under the Synar grazing fee proposal (Synar et al. 1991), higher fees would have been phased in over 4 years with \$4.35/AUM the first year, \$5.80/AUM the second, \$7.25/AUM the third, and $\$ 8.70 /$ AUM or fair market value, whichever was higher, in year 4 and thereafter. The phase-in fees of the Synar proposal were considered for the first 4 years in the LP models with an assumed constant \$8.70/AUM fee after that. The value of federal grazing permits were assumed to be eliminated, reducing ranch borrowing capacity.

\section{Estimating Total Impacts to Current GNF Ranchers}

A total of 366,094 AUMs were permitted for grazing use on the Gila National Forest (GNF) during 1992. These AUMs were allo- cated to 132 grazing permittees using 143 allotments (personal communication, Chuck Sundt, USFS-GNF range specialist, March 1993). National forest grazing records indicate approximately $15 \%$ of the AUMs are used by ranchers classified with small herd sizes ( $<<150$ AUY) when categorized according to NMSU budgets. Similarly, $27 \%$ of the AUMs are permitted for

Table 3. Livestock production parameters, land acreage and forage sources for representative ranches using the GNF in 1992.

\begin{tabular}{|c|c|c|c|}
\hline & Small & Medium & Large \\
\hline \multicolumn{4}{|c|}{ Livestock production parameters and herd size } \\
\hline Number of mature cows & 86 & 230 & 517 \\
\hline Number of AUY & 113 & 301 & 667 \\
\hline Cows per bull & 13 & 13 & 13 \\
\hline Number of horses & 4 & 10 & 14 \\
\hline Cow replacement rate $(\%)$ & 14 & 14 & 14 \\
\hline Calf death loss (\%) & 4 & 4 & 4 \\
\hline Yearling death loss (\%) & 2 & 2 & 2 \\
\hline Cow death loss (\%) & 2 & 2 & 2 \\
\hline Bull death loss (\%) & 1 & 1 & 1 \\
\hline Calf crop (\%) & 76 & 76 & 76 \\
\hline Productive life of bulls & 5 & 5 & 5 \\
\hline \multicolumn{4}{|l|}{ Sale weights } \\
\hline Cull cows & 910 & 910 & 910 \\
\hline Cull bull & 1,475 & 1,475 & 1,475 \\
\hline Yearling heifers & 740 & 740 & 740 \\
\hline Yearling steers & 760 & 760 & 760 \\
\hline Heifer calves & 410 & 410 & 410 \\
\hline Steer calves & 460 & 460 & 460 \\
\hline \multirow{2}{*}{\multicolumn{4}{|c|}{$\begin{array}{l}\text { Land acreages and forage sources } \\
\text { Owned rangeland }\end{array}$}} \\
\hline & & & \\
\hline Acres & 650 & 4,339 & 8,532 \\
\hline AUMs & 98 & 651 & 1,440 \\
\hline$\%$ of total AUMs & $7 \%$ & $18 \%$ & $18 \%$ \\
\hline \multicolumn{4}{|l|}{ State Lease } \\
\hline Acres & 0 & 2,893 & 5,689 \\
\hline AUMs & 0 & 434 & 960 \\
\hline$\%$ of total AUMs & 0 & 12 & 12 \\
\hline \multicolumn{4}{|l|}{ U.S. Forest Service } \\
\hline Acres & 8,350 & 16,876 & 33,181 \\
\hline AUMs & 1,253 & 2,531 & 5,599 \\
\hline$\%$ of total AUMs & $93 \%$ & $70 \%$ & $70 \%$ \\
\hline
\end{tabular}


Table 4. Costs and returns for represetnative GNF ranches with alternative levels of current debt obligation, 1992.

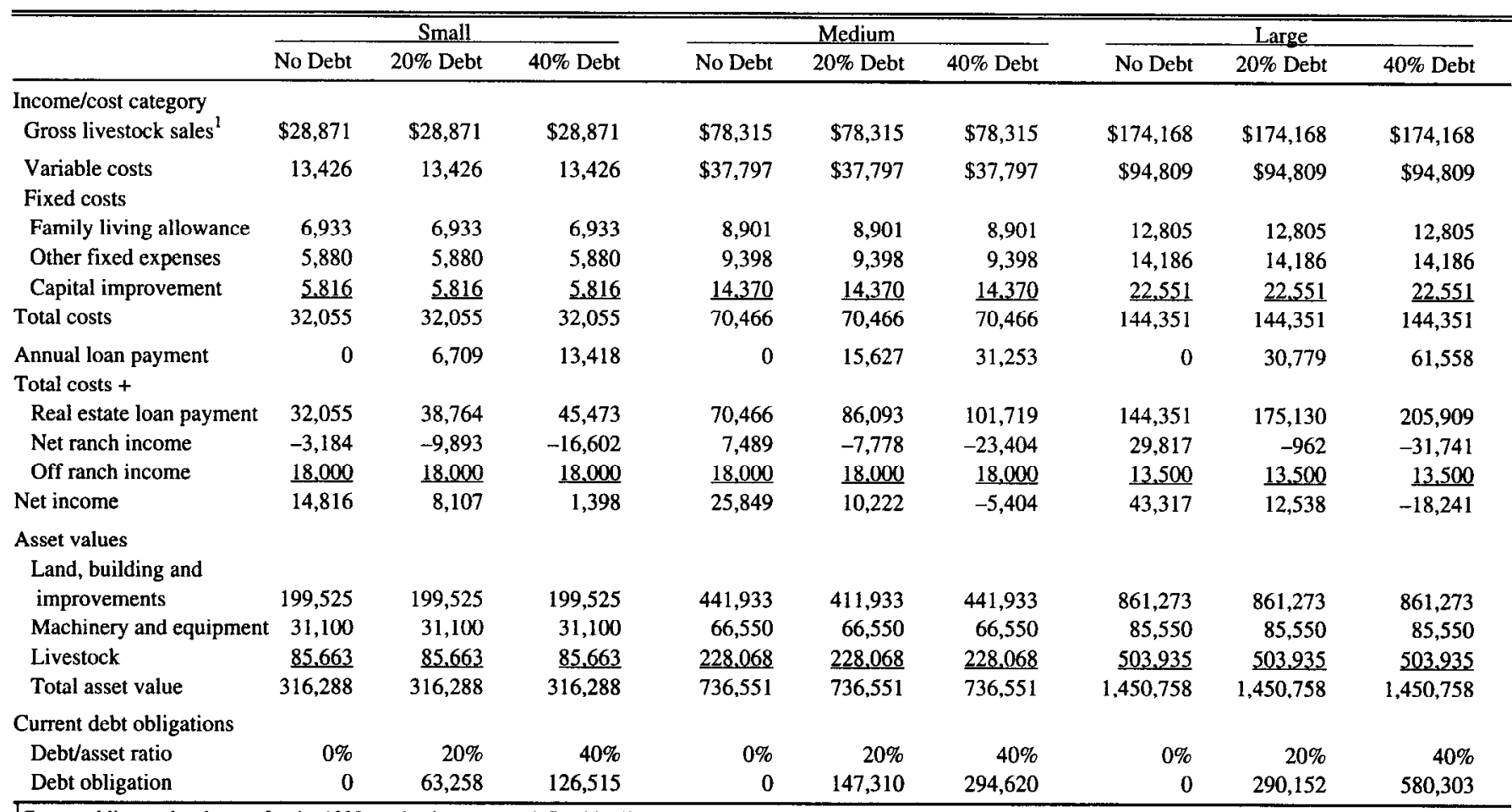

Costs and livestock sales are for the 1992 production year as defined by Torell et al. (1993a,b,c). Costs and returns during other years considered in the LP analysis varied with beef prices and optimal level of production.

use by medium-size ranches (150 AUY $\leq \mathrm{S} \leq 350 \mathrm{AUY})$, and $58 \%$ by large-size ranches ( $\mathrm{S}>350 \mathrm{AUY}$ ). Using these percentages, ranchers with small, medium, and large herd sizes are permitted to use 54,536 AUMs, 97,737 AUMs and 213,821 AUMs of USFS grazing on the GNF, respectively.

New Mexico State University (NMSU) ranch budgets were not defined from grazing use records for the GNF; thus, some discrepancy in average herd size, forage use, and level of forest dependency would be expected. It is important, however, that an impact assessment consider the correct number of federal AUMs when aggregating to the total. Thus, the number of ranchers considered in the analysis was not defined to be the actual number using the GNF. Rather, it was the equivalent number of ranchers based on USFS AUM use. This was calculated by dividing the total AUMs of permitted use on the GNF (by size category) by the average AUMs of USFS use defined for each NMSU ranch budget. Table 5 gives the 9 types of ranch models developed, and the multipliers used to aggregate from ranch-level impacts to total impacts for current GNF ranchers.

\section{Results}

Results are presented and discussed in the following order. First, optimal production for each ranch size with the 1992 PRIA fee of $\$ 1.92 / A U M$ is defined for ranchers using the Gila National Forest (GNF), given the defined costs, prices, and model assumptions. Next, optimal production under alternative grazing fee proposals are evaluated and compared to the PRIA base run. Results are then aggregated to estimate total impacts to ranchers using the GNF and total grazing fee receipts to the USFS.
A detailed listing of optimal solution values for each of the 60 years considered in the analysis is not given because optimal forage use and livestock production strategies were similar between years. However, net ranch returns varied considerably between years depending on the definition of annual beef prices. Drummond (1993) provides a detailed listing of annual LP solution values. ${ }^{2}$

\section{Optimal ProductionStrategies: Current PRIA Grazing Fees Small Ranches}

An optimal production strategy was found for each of the 3 assumed debt loads. Small ranches with no current debt and with a $20 \%$ debt/asset ratio would optimally borrow no additional funds. The ranch with a $40 \%$ debt/asset ratio would not have enough production and sales to cover expenses during years with low beef prices, such as years 5 through 8 (Table 2), and would borrow to meet cash shortfalls. It would take several years of continued borrowing to catch up. Once the long-term land loan was fully paid in year 30 , additional funds would not be borrowed.

Forage was a limiting resource during all years. Deeded AUMs would always be used to capacity. Similarly, the maximum number of USFS AUMs were used in all years, except the first year when herd size was restricted and the last year when all cows would optimally be sold.

The optimal number of brood cows was relatively constant, ranging from a low of 81 head to a high of 88 head. $^{3}$ Optimal pro-

\footnotetext{
${ }^{2}$ Drummond presents the results of a $\$ 4.28 /$ AUM grazing fee as originally proposed by USDU/USDA (1993) versus the \$3.96/AUM fee considered here. Annual returns were different but optional production strategies were the same.
} 
Table 5. Number of ranches and USFS AUMs used to aggregate to total GNF ranch-level impacts for current permit holders.

\begin{tabular}{|c|c|c|c|c|c|c|}
\hline \multirow[b]{2}{*}{ Ranch Size } & & \multicolumn{3}{|c|}{ Debt/Asset Ratio } & \multicolumn{2}{|r|}{$\%$ of Total } \\
\hline & & $0 \%$ & $20 \%$ & $40 \%$ & Total & Ranches \\
\hline \multirow[t]{2}{*}{ Small } & USFS AUMs & 19,769 & 28,555 & 6,590 & 54,914 & 15 \\
\hline & No. ranches & $23(16)^{1}$ & $34(23)$ & $8(5)$ & $65(44)$ & $49(36)$ \\
\hline \multirow[t]{2}{*}{ Medium } & USFS AUMs & 35,584 & 51,399 & 11,861 & 98,845 & 27 \\
\hline & No. ranches & $14(14)$ & $20(20)$ & $4(5)$ & $38(39)$ & $29(32)$ \\
\hline Large & USFS AUMs & 76,441 & 110,414 & 25,480 & 212,335 & 58 \\
\hline & No. ranches & $47(44)$ & $69(63)$ & $16(14)$ & $132(121)$ & \\
\hline & Percent of total $(\%)$ & 36 & 52 & 12 & 100 & \\
\hline
\end{tabular}

${ }^{1}$ The first number shown is the actual number of GNF ranches estimated to be in this category. The bracketed () number is the equivalent number of ranches of equal size to NMSU ranch budgets.

duction was as a cow/calf ranch, similar to the ranches currently found on the Gila National Forest (GNF). Retaining calves for sale as yearlings was not optimal during any of the production years.

Table 6 defines average annual net returns and the optimal NPV found for each ranch size and debt load. With no debt, the small ranch returned $\$ 215,642$ in discounted net returns to operator labor, management, and owned capital. ${ }^{4}$ Annual income over the 60-year planning period was estimated to average $\$ 15,195$ for the no-debt ranch, $\$ 11,841$ for the $20 \%$ debt/asset ratio ranch and $\$ 8,118$ for the $40 \%$ debt/asset ratio ranch. Annual returns varied from about $\$ 6,300$ to $\$ 25,000$ depending on beef prices.

\section{Medium Ranches.}

An optimal linear programming (LP) solution was not possible for the high debt model because cash flow requirements could not be met for the medium size ranch. Annual net returns were estimated to average $\$ 26,665$ for the no-debt model and $\$ 10,794$ for the $20 \%$ debt model. They varied from about $-\$ 600$ to $+\$ 54,000$ for the no-debt ranch, and from $-\$ 21,000$ to $+\$ 38,300$ for the $20 \%$ debt ranch. Negative returns during some years were covered by either borrowing or inter-year fund transfers.

The no-debt ranch would not optimally borrow any money, and available forage would always limit production. The $20 \%$ debt/asset ranch borrowed approximately $\$ 14,000$ of short-term capital in years 7 through 10 and again in years 20 through 23 because of the relatively low beef prices and resulting cash flow shortages during these years. The optimal number of brood cows ranged from 215 to 235 head, while forage use remained relatively constant over the planning period.

\section{Large Ranches}

Average annual returns were estimated to be $\$ 46,171$ for the large no-debt ranch and $\$ 13,913$ for the $20 \%$ debt/asset ranch (Table 6). Cash flow restrictions could not be met for the $40 \%$ debt/asset model (infeasible). Net annual returns varied from

\footnotetext{
${ }^{3}$ It should be recognized that only a limited number of possible production options were considered to be feasible for GNF ranchers. Production options like purchase of yearling stockers, leasing forage, or investing funds elsewhere were not considered. Including more production options would be expected to cause greater variation in optimal cow herd size.

${ }^{4}$ This residual return does not follow the traditional definition because a family living allowance has already been subtracted. This allowance would be a partial payment for operator labor and management.
}

about $+\$ 1,000$ to over $+\$ 220,000$ for the no-debt ranch, and from $-\$ 65,000$ to $+\$ 191,000$ for the $20 \%$ debt ranch. The optimal number of brood cows ranged from 425 to 530 head.

\section{Optimal Production Strategies: Rangeland Reform ‘94} Small Ranches.

The average \$2.04/AUM fee increase proposed in Rangeland Reform '94 (\$3.96/AUM-\$1.92/AUM) would mean a $\$ 2,556$ decrease in net annual small ranch returns if the strategy were to pay the higher fee on all available USFS AUMs. This was the optimal strategy during all years except the first and second years. Herd size was restricted during the first year and not adjusted to full capacity until year 3 with the higher fee. Optimal herd size and marketing strategies would remain unchanged between the 2 grazing fee situations once the fee was fully implemented.

With the grazing fee at \$3.96/AUM, the small ranch with $20 \%$ debt would borrow about $\$ 1,000$ in short-term funds during the 7 th, 8 th, 21st, and 22nd years. With a long-term debt payment due each year until the 30th year, funds would be limiting and production strategies would be altered slightly for this reason.

The small-size ranch with a $40 \%$ debt/asset ratio was infeasible at the $\$ 3.96 / \mathrm{AUM}$ grazing fee, as the model could not meet cash flow restrictions during selected years and repay all debt obligations. Thus, it is estimated that small-size Gila National Forest (GNF) ranchers with high debt (approximately 4\% of the current GNF ranchers) would face cash flow shortages if fees were increased to $\$ 3.96 /$ AUM (Table 8).

With a $40 \%$ debt/asset ratio and at the current fee, the small ranch made an average annual return over variable costs of $\$ 15,456$ (Table 6). This was $\$ 12.34 /$ USFS AUM, and this amount would be the average annual loss in net ranch income (NRI) from these high-debt small ranches going out of business.

Additional computer runs were made (not shown) to determine the maximum grazing fee at which small high-debt ranchers could still meet cash flow restrictions. This fee was estimated to be \$3.15/AUM. At this fee, cash flow restrictions could be met by pushing to the maximum borrowing limit and rolling debt forward until the last year of the 60 year planning period when assets were sold. However, it is unlikely this strategy would be financed by even the most trusting banker. 
Table 6. Average net ranch returns for representative GNF ranchers at the 1992 PRIA fee of \$1.92/AUM.

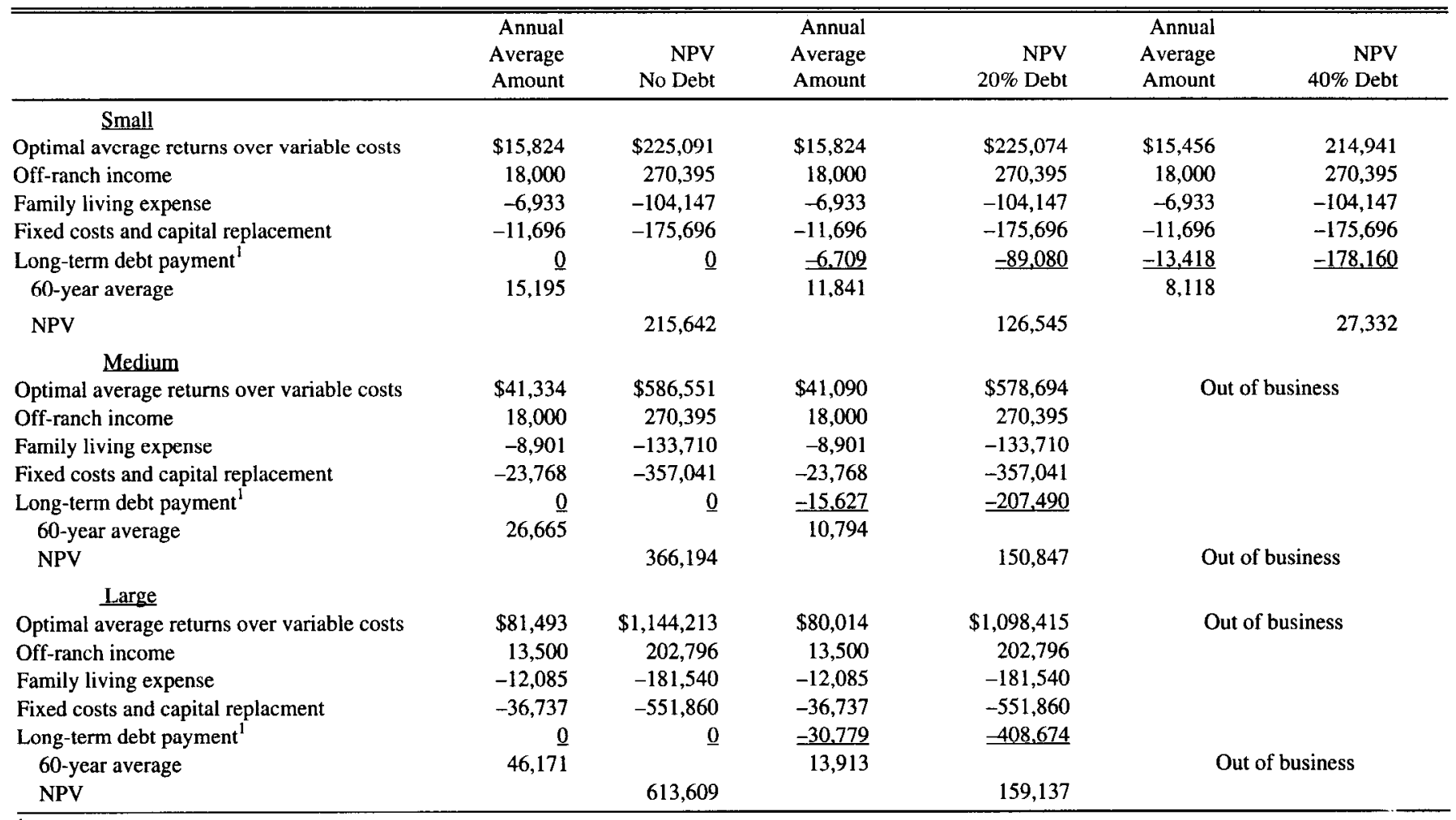

${ }^{1}$ Long-term debt payment is only incurred during the first 30 days of the analysis.

\section{Medium Ranches}

The model results for the no-debt medium size ranch with grazing fees of \$1.92/AUM versus \$3.96/AUM were similar to those of the small ranch. The optimal strategy would be to pay the higher fee unless forced out of business by cash flow restrictions. Net returns would decrease by the amount of the added grazing fee payment, $\$ 5,163 /$ year.

The medium-size ranch with a $20 \%$ debt/asset ratio would have to increase the amount of borrowed funds and switch to intermediate-term borrowing during some years to meet cash flow restrictions. Because of increased interest payments, the average change in annual net returns would be $-\$ 5,511 /$ year, an amount greater than the increase in grazing fees.

With the defined situation the medium ranch model was infeasible at the high-debt level even at the 1992 federal fee rate of \$1.92/AUM. Additional computer runs indicate the cash flow restrictions of the model could not be met even if the grazing fee were zero.

\section{Large Ranches}

With the grazing fee increase to $\$ 3.96 / \mathrm{AUM}$, the large ranch with no debt would have to borrow about $\$ 11,000$ during selected years when beef prices were relatively low. There was a slight change in marketing strategies between years but as a 60 -year average only 4 fewer animal units yearlong (AUY) were produced each year. An annual average of 193 USFS AUMs would go unused.

Similar to the large ranch model with $40 \%$ debt, which was infeasible even at the current fee, the large ranch with a $20 \%$ debt/asset ratio became infeasible at the $\$ 3.96 / \mathrm{AUM}$ fee. Large size Gila National Forest (GNF) ranches with intermediate debt, approximately $11 \%$ of the current GNF ranches (Table 5), could not meet cash flow restrictions if grazing fees were increased to $\$ 3.96 /$ AUM. As indicated by additional computer runs, cash flow restrictions could be fulfilled with a grazing fee of about $\$ 3.50 /$ AUM.

\section{Optimal Production Strategies: Synar Proposal}

With the Synar proposed fee of $\$ 8.70 /$ AUM, production strategies were similar for the 3 ranch sizes; in most cases there would be no production. Cash flow restrictions could not be met by any of the ranches with debt, and for those ranches with no debt, major changes in production would be optimal. Livestock production would be cyclic with USFS AUMs going unused in low beef price years but used fully when beef prices were relatively high. Averaged over all years, for the small no-debt ranch, optimal herd size was reduced from 113 AUY with the PRIA fee to 92 AUY with the $\$ 8.70 /$ AUM fee. Similarly, optimal herd size was reduced from 301 AUY to 273 AUY for the medium no-debt ranch, and from 667 AUY to 424 AUY for the large no-debt ranch.

Short and intermediate-term borrowing would optimally be used to cover annual expense shortfalls and to purchase brood stock as herd size was adjusted to changing economic conditions. By making these adjustments, the reduction in net returns from the higher fee was minimized. The small no-debt ranch, for example, would have realized an annual decrease in net returns of $\$ 8,495$ (\$6.78/AUM fee increase $\times 1,253$ AUMs) if grazing fees had been paid on all USFS AUMs. By letting some AUMs go unused in selected years, the average decrease in net returns was reduced to $\$ 8,391 /$ year. 
Table 7. Total number of current GNF ranchers 0 and AUM use by these ranchers at alternative fee rates.

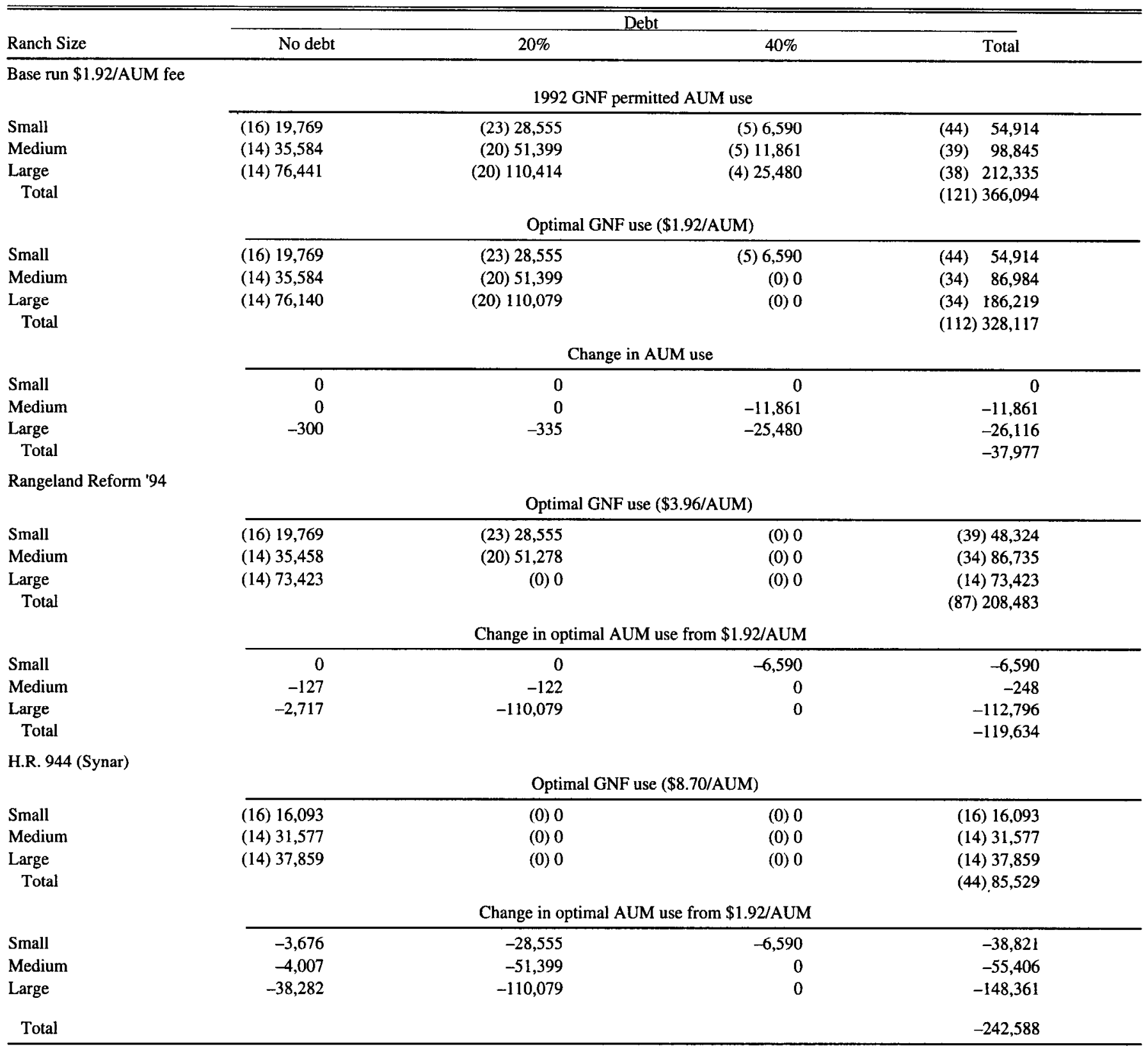

\section{Total Impacts to Current GNF Permit Holders}

Ranch Numbers.

The estimated number of current GNF ranches that would be producing under alternative grazing fee proposals is shown in Table 7 . The medium and large $40 \% \mathrm{debt} /$ asset ratio ranch models could not meet cash flow restrictions at the current grazing fee and are estimated to be on their way out of business without additional off-ranch income. The loss of these ranches is expected with or without increased grazing fees and altered land-use policies. It would be expected that the equivalent number of current Gila National Forest (GNF) ranches would decrease from 121 to 112 under current grazing fee policy.

With an increase in federal grazing fees to \$3.96/AUM, the small $40 \%$ debt/asset ranch and the large $20 \%$ debt/asset ranch were estimated to go out of business. With these 2 ranch cate- gories no longer operating, the number of equivalent ranches would decrease to 87 . A still higher fee of $\$ 8.70$ /AUM would decrease the number to 44 ranches.

The only ranches still producing at the \$8.70/AUM fee would be those with no debt. This assumes remaining ranchers would continue in business and not decide that other investments would be more advantageous.

It might be expected that with increased grazing fees and with added regulations, ranchers other than those forced out of business would choose to quit. But, as a counter point, because grazing permit values should decrease by an amount equal to or greater than the loss in discounted net returns, new ranchers should be able to buy Gila National Forest (GNF) ranches at a Inuch lower price and still cash flow the investment, provided large debts are not incurred to make the ranch purchase. The 
grazing permit could also be attached to another existing ranch. Thus, the exact number of ranches using the GNF with different fees cannot be determined. The estimates provided here refer only to the expected change in production from current ranchers, given their defined size, production levels, and debt structure.

\section{GNF AUM Use and Grazing Fee Receipts}

Total Gila National Forest (GNF) permitted use during 1992 was estimated to be 366,094 AUMs (Table 5). Actual use averaged $71 \%(259,306$ AUMs) of this amount from 1986 to 1991. The optimal annual use by current permit holders, as estimated from the linear programming (LP) analysis, would average 328,117 AUMs (Table 7). Optimal average USFS use at the $\$ 3.96 /$ AUM fee was 208,483 AUMs. It dropped substantially to only 85,529 AUMs at a fee of $\$ 8.70 / \mathrm{AUM}$, as only ranchers with little if any debt would remain in business at this fee.

Even though Gila National Forest (GNF) AUM use by current permit holders would decrease with higher grazing fees, optimal forage use was price inelastic (the \% decrease in quantity of forage demanded was less than the \% increase in price) with GNF revenue increasing at the higher fees. Relative to the 1992 $\$ 1.92 / A U M$ fee, average annual grazing fee receipts would increase by $\$ 195,798$ at $\$ 3.96 / A U M$ and by $\$ 118,877$ at the $\$ 8.70 / A U M$ fee. Because grazing fee receipts would be higher at the \$3.96/AUM fee, not the \$8.70/AUM fee, the demand for GNF forage is estimated to be price elastic over this higher price range. The price elasticity of demand was estimated to be -0.64 (a $1 \%$ increase in price caused a $0.64 \%$ decrease in AUM use) for the fee change from \$1.92/AUM to \$3.96/AUM, and -1.11 for the change from $\$ 3.96 / A U M$ to $\$ 8.70 /$ AUM.

\section{Livestock Receipts}

Optimal average annual livestock receipts from current GNF ranchers at the \$1.92/AUM PRIA fee totaled \$9,988,307 (Table 8). This decreased to $\$ 6,300,637$ at the $\$ 3.96 /$ AUM fee, a $37 \%$ decrease. Optimal annual livestock receipts for current GNF ranchers at a grazing fee of $\$ 8.70 / A U M$ would average $\$ 3,452,686$, a $65 \%$ decrease.

\section{Net Ranch Income}

Average annual net ranch income for current GNF ranchers at the $\$ 1.92 / A U M$ fee level was estimated to be $\$ 4,797,640$ (Table 9). It dropped to $\$ 2,703,426$ (44\% decrease) with a $\$ 3.96 /$ AUM fee and to $\$ 916,062$ (81\% decrease) with an $\$ 8.70$ /AUM fee. The reduction in NRI was about equal to the fee increase if ranchers remained in business.

\section{Conclusions and Discussion}

Higher grazing fees will reduce ranch income and net worth. Some ranchers will go out of business, but if the grazing fee remained at or below the $\$ 3.96 / \mathrm{AUM}$ rate proposed in Rangeland Reform ' 94 the optimal strategy would be to pay the higher fee unless high current debt created cash flow limitations. If permit values fall because of higher grazing fees and new regulations, as

Table 8. Annual average livestock receipts from current GNF ranchers at alternative fee leve

\begin{tabular}{|c|c|c|c|c|}
\hline \multirow[b]{2}{*}{ Ranch Size } & \multicolumn{4}{|c|}{ Debt } \\
\hline & No debt & $20 \%$ & $40 \%$ & Total \\
\hline \multicolumn{5}{|c|}{ Base run \$1.92/AUM fee } \\
\hline & \multicolumn{4}{|c|}{ Optimal livestock receipts (\$ Total @ \$1.92/AUM fee) } \\
\hline Small & $\$ 466,048$ & $\$ 673,180$ & $\$ 159,862$ & $\$ 1,299,089$ \\
\hline Medium & $1,113,036$ & $1,623,173$ & 0 & $2,736,209$ \\
\hline Large & $2,391,830$ & $3,561,178$ & 0 & $5,953,009$ \\
\hline Total & & & & $9,988,307$ \\
\hline \multicolumn{5}{|c|}{ Rangeland Reform '94 } \\
\hline & \multicolumn{4}{|c|}{ Optimal livestock receipts (\$ Total @ \$3.96/AUM fee) } \\
\hline Small & $\$ 465,937$ & $\$ 673,225$ & $\$ 0$ & $\$ 1,139,163$ \\
\hline Medium & $1,112,727$ & $1,657,026$ & 0 & $2,769,753$ \\
\hline Large & $2,391,721$ & 0 & 0 & $2,391.721$ \\
\hline \multirow[t]{2}{*}{ Total } & & & & $6,300,637$ \\
\hline & \multicolumn{4}{|c|}{ Average change in livestock receipts from \$1.92/AUM (\$ Total) } \\
\hline Small & $-\$ 110$ & $\$ 46$ & $-\$ 159,862$ & $-\$ 159,926$ \\
\hline Medium & -309 & 33,853 & 0 & 33,544 \\
\hline Large & -109 & $-3,561,178$ & 0 & $-3,561,288$ \\
\hline Total & & & & $-3,687,670$ \\
\hline \multicolumn{5}{|c|}{ H.R. 944 (Synar) } \\
\hline & \multicolumn{4}{|c|}{ Optimal livestock receipts (\$ Total @ \$8.70/AUM fee) } \\
\hline Small & $\$ 451,706$ & $\$ 0$ & $\$ 0$ & $\$ 451,706$ \\
\hline Medium & $1,084,777$ & 0 & 0 & $1,084,777$ \\
\hline \multirow{3}{*}{$\begin{array}{l}\text { Large } \\
\text { Total }\end{array}$} & $1,916,203$ & 0 & 0 & 1.916 .203 \\
\hline & & & & $3,452,686$ \\
\hline & \multicolumn{4}{|c|}{ Average change in livestock receipts from \$1.92/AUM (\$ Total) } \\
\hline Small & $-\$ 14,342$ & $-\$ 673,180$ & $-\$ 159,862$ & $-\$ 847,383$ \\
\hline Medium & $-28,259$ & $-1,623,173$ & 0 & $-1,651,432$ \\
\hline Large & $-475,627$ & $-3,561,178$ & 0 & $=4.036 .806$ \\
\hline Total & & & & $-6,535,621$ \\
\hline
\end{tabular}


Table 9. Average annual net ranch income (NRI) for GNF ranchers at alternative fee levels.

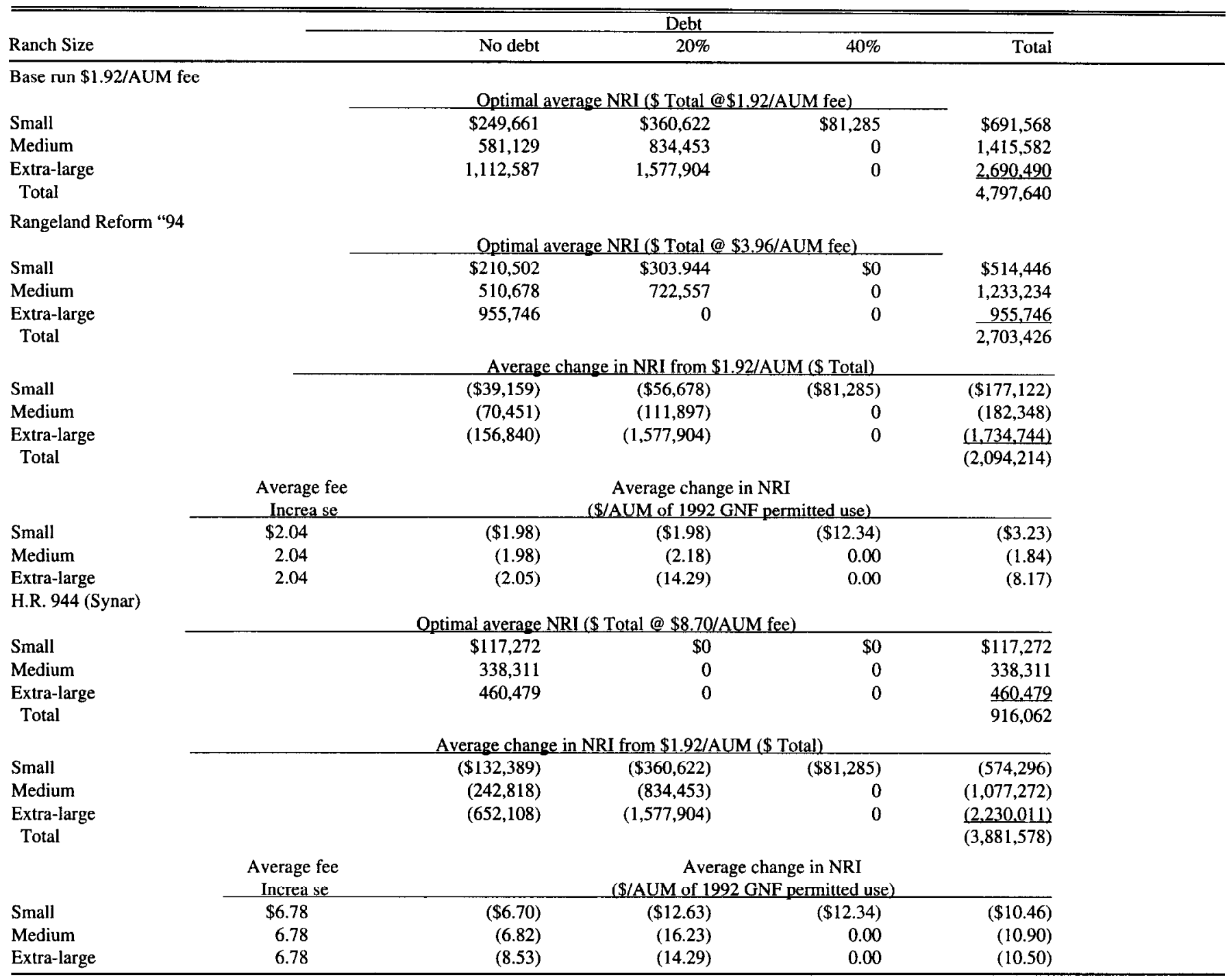

would bc expected, proposed policy changes might mean an opportunity for new ranchers to lease these permits without a large purchase cost for the permit.

The ones who lose with higher grazing fees are current public land ranchers. In addition to decreased net annual returns, these producers would likely see a major decline in ranch value as earning potential decreases. Because debt load was found to be a major determinant of the ability to cash flow the ranching business, the implications for bankers and lenders is significant. Further, it is not small size ranch units that would most likely go out of business, as is widely believed; rather, it is those with high to intermediate debt obligations. Off-ranch income is a major part of family income for small part-time ranchers. Because higher debt is generally held by younger farmers and ranchers (NMDA 1990) this group would potentially be most impacted from increased grazing fees.

In this analysis a modeling and cash flow evaluation was conducted with specific assumptions about debt load, off-ranch income, production rates, and costs. When income was insufficient to pay all annual production expenses, a minimal family liv- ing allowance, and debt obligations, the ranch was considered to be "out of business." As shown, with grazing fees in the range of $\$ 3$ to $\$ 4 / A U M$ some ranchers will leave the livestock business, especially those with high debt. Still others would be expected to enter and leave the business as ranch values and the economics of ranching change from altered land-use policies and market conditions.

The conclusion that the fee proposals of Rangeland Reform '94 will force some ranchers out of business is different than that reached by Richardson et al. (1993). These authors found that the proposed fees of Rangeland Reform ' 94 would not force representative ranches out of business over the next 6 years. The difference in conclusions might be because the previous study considered ranches that graze rangelands on a seasonal basis and are less dependent on federal lands for grazing capacity.

Grazing fees averaging \$8.70/AUM would force many ranchers out of business and grazing fee receipts would be less than what could be obtained at a lower fee. This fee is too high if continued grazing use of public lands is desired. 


\section{Literature Cited}

Brooke, A., D. Kendrick, and A. Meeraus. 1992. GAMS: A user's guide, Release 2.25. The Scientific Press, San Francisco, Calif.

Drummond, T.W. 1993. The economic impacts of increased grazing fees on Gila National Forest ranchers. Master's Thesis. New Mex. State Univ., Las Cruces, N.M.

Fowler, J.M., D. Rush, J.M. Hawkes, and T.D. Darden. 1994. Economic characteristics of the western livestock industry. New Mex. State Univ. RITF Report 35.

Gee, C.K. 1981. Estimating economic impacts of adjustments in grazing on federal land and estimating federal rangeland forage values. Colorado State Univ. Exp. Sta. Tech. Bul. 143. Fort Collins, Colo.

Nadler, J. 1995. House Resolution 676. U.S. House of Representatives, U.S. Congress, Washington, D.C.

New Mexico Economic Development Dept. 1992. New Mexico fact book. Santa Fe, N.M.

New Mexico Department of Agriculture (NMDA). 1990. New Mexico agriculture finance survey. Las Cruces, N.M.

Olson, C.E. and J.W. Jackson. 1975. The impacts of change in federal grazing policies on south central Wyoming mountain valley cattle ranches. Wyom. Agr. Exp. Sta. Res. Jour. 96. Laramie, Wyo.

Peryam, J.S. and C.E. Olson. 1975. Impact of potential changes in BLM grazing policies on west-central Wyoming cattle ranches. Wyoming Agr. Exp. Sta. Res. Jour. 87. Laramie, Wyo.

Richardson, J.W., D.P. Anderson, R.D. Knuston, and B.T. Young 1993. The ranch level impacts of proposed public land grazing fees. Agriculture and Food Policy Center. Briefing Series 93-8. Dept. of Agric. Econ. Tex. A\&M Univ. College Station, Tex.

Synar, M., G. Darden, R.T. and C. Atkins. 1991. House Resolution 944. U.S. House of Representatives, U.S. Congress, Washington, D.C.

Tchand, M.N. 1992. Cost and return estimates for nontraditional yearling production alternatives in Catron County, New Mexico. M.S. Thesis, New Mexico State Univ., Las Cruces, N.M.

Torell, L.A. and M.E. Kincaid. 1996. Public land policy and the value of New Mexico ranches. J. Range Manage.

Torell, L.A., T.J. Bagwell, W.B. Word, and D.A. Baird. 1993a. 1992 Cost and returns for a small cow/calf ranch grazing on the Gila National Forest. New Mex. State Univ., Cooperative Extension Service. CRE92-LA-CA1. Las Cruces, N.M.

Torell, L.A., T.J. Bagwell, W.B. Word, and D.A. Baird. 1993h. 1992 Cost and returns for a medium cow/calf ranch grazing on the Gila National Forest. New Mex. State Univ., Cooperative Extension

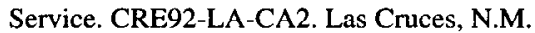

Torell, L.A., T.J. Bagwell, W.B. Word, and D.A. Baird. 1993c. 1992 Cost and returns for an extra-large cow/calf ranch grazing on the Gila National Forest. New Mex. State Univ., Cooperative Extension Service. CRE92-LA-CA3. Las Cruces, N.M.

Torell, L.A., L. Brence, and W.B. Word. 1994. The economic impacts to New Mexico ranchers of increasing grazing fees to levels proposed in Rangeland Reform ' 94 and by legislative compromise. New Mex. State Univ, RITF Report 36.

Torell, L.A., J.R. Garrett, and C.T.K. Ching. 1981. The economic effect of three changes in public lands grazing policies. J. Range Manage. 34:373-376.

U.S. Department of Agriculture, Forest Service, and U.S. Department of Interior, Bureau of Land Management (USDA/USDI). 1986. Grazing fee review and evaluation final report 1979-1985: A report from the Secretaries of Agriculture and Interior. Washington, D.C

U.S. Department of Agriculture, Forest Service, and U.S. Department of Interior, Bureau of Land Management. 1992. Grazing fee review and evaluation update of the 1986 final report: A report from the Secretaries of Agriculture and Interior. Washington, D.C.
U.S. Department of Interior, Bureau of Land Management and United States De partment of Agriculture, Forest Service (USDI/USDA). 1993. Rangeland Reform ` 94 . Washington, D.C.

U.S. Department of Interior, Bureau of Land Management and United States De partment of Agriculture, Forest Service (USDI/USDA). 1994a. Rangeland Reform `94: Draft Environmental Impact Statement. Washington, D.C.

U.S. Department of Interior, Bureau of Land Management and United States De partment of Agriculture, Forest Service (USDI/USDA). 1994b. Rangeland Reform `94: Draft Environmental Impact Statement Executive Summary. Washington, D.C.

Wilson, J.R., G. Marousek, and C.K. Gee. 1985. Economic impacts of BLM grazing policies on Idaho cattle ranchers. Univ of Idaho Agr. Exp. Sta. Res. Bul. 136. Moscow, Idaho. 